\title{
Societies join forces to lobby Congress
}

Washington. The major US professional societies representing physicists, chemists and biologists are to join forces in a lobbying offensive designed to persuade Congress to increase support for basic science, and in particular for the National Science Foundation (NSF).

The move follows an awareness that energetic lobbying over the past two years by the Federation of American Scientists for Experimental Biology (FASEB) has played a substantial role in securing a budget increase of about 6 per cent in each year for the National Institutes of Health (NIH). In contrast, the NSF has seen its budget increase by only about 2 per cent.

The presidents of FASEB, the American Chemical Society (ACS), and the American Physical Society (APS) met last month to discuss a joint lobbying strategy for the budget for fiscal year 1998 (which starts next October). Afterwards they told their government relations staff in Washington to work out details of a joint approach to key congressional leaders.

Such details have not yet been agreed. But officials at each of the three groups say that they plan to make their case in Congress in time to influence the 1998 budget, proposals for which will be submitted by the Clinton administration to Congress in February, before it is split up for consideration by separate appropriations subcommittees.

The idea for the joint approach sprang from concern that the NSF has not done as well as it could have in the past two budget cycles, despite the stated view of congressional leaders that they support basic science. Additionally, society officials especially Ron Breslow, this year's president of the ACS - feel strongly that relations between the societies ought to be improved.

The APS and ACS have not enjoyed good relations in recent years. For example, they engaged in a long, semi-public feud over the 'Science in American Life' exhibition at the Smithsonian Museum in Washington (see Nature 380, 95; 1996). Both have enviously eyed FASEB's success in lobbying for funds for biomedical research at the NIH.

Last month, FASEB invited officials from APS and ACS to its annual 'consensus' meeting, at which representatives of the biology federation's member societies discussed their approach to next year's Congress.

The meeting is organized to help FASEB to agree an NIH funding 'target' which, in the past two years, has proved an accurate prediction of NIH's funding prospects. According to one FASEB official, this year the federation may also publish a 'target' for the NSF as well.

Mike Lubell, of the APS's government affairs office, says that the three groups "are moving rather vigorously" towards an agreement. "We hope to be geared up by February," he says. The APS's physics planning committee has set up a subgroup, chaired by Pierre Hollinberg of Yale University, to develop links with other disciplines.

"The time has come for Congress to understand that science cannot be divided up into little pieces," says Lubell. He says

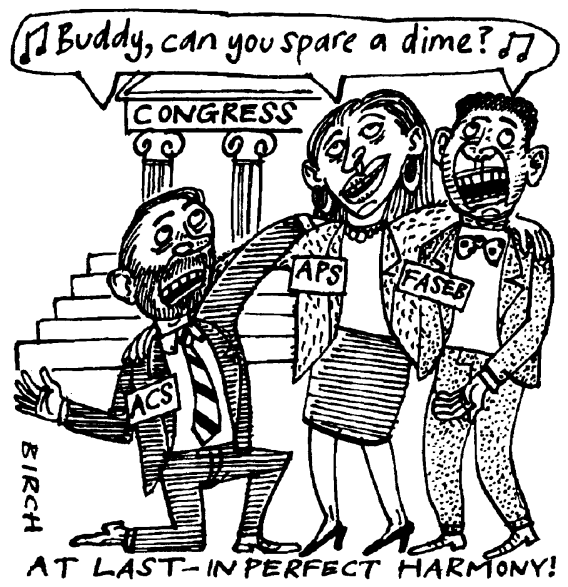

that targets for joint lobbying will include Bob Livingston (Republican, Louisiana), chair of the House of Representatives Appropriations Committee, and James Sensenbrenner (Republican, Wisconsin), chair of the House Science Committee.

The chemical society, with 152,000 members and an annual income of $\$ 260$ million (mainly from publishing), is larger than the other two groups combined. Its physics counterpart has 40,000 members and an income of $\$ 30$ million, while the biology federation has an income of $\$ 12$ million, and its member societies have 43,000 members.

The ACS tends to be dominated by industrial chemists and engineers, and critics contend that it has not wielded as much influence as it could have done on science issues. Breslow, a professor of chemistry at Columbia University in New York, says that he has agreed the principle of a joint approach with the other two groups, and might invite others to join in later.

"We think that presenting the case for science together makes a lot of sense," says Breslow. "We are bigger than they are, but that's not the point: FASEB and the APS are both pretty well-connected in Washington."

John Suttie, FASEB president and a professor of biochemistry and nutrition at the University of Wisconsin at Madison, is cautious about the plan, saying that "we have not decided how to proceed to the next step". But "something will be done", he adds.

FASEB, says Suttie, acknowledges that efforts to win funding for the life sciences directorate alone at NSF are ineffective, as the directorate gets a fixed proportion of NSF's total. He thinks that a unified message will go down well in Congress: "We can't afford to have scientists squabbling," he says.

Colin Macilwain

\section{UK human genetics panel established}

London. The United Kingdom's new Human Genetics Advisory Commission is to be chaired by Sir Colin Campbell, vice-chancellor of the University of Nottingham and former chairman of the Human Fertilization and Embryology Authority. The commission's full membership was announced on Monday (2 December) by lan Taylor, minister for science and technology.

The 10-member commission was called for by the House of Commons Select Committee on Science and Technology in July 1995. The government initially rejected the suggestion as "unnecessary" (see Nature 379, 195; 1996), but later changed its mind, accepting that such a commission might help to allay public fears of developments in genetic science.

According to Campbell, the commission will advise the government when it believes that new legislation is necessary. But its role is also "oriented to informing the public and listening to the public", and in particular to emphasizing to the government and the public where "promise or danger" might lie in new scientific developments.

Taylor expects the commission to be "capable of anticipating fears" that the public might have about new genetic technologies, to prevent "disproportionate reactions" that might hold back successful exploitation of such research. Reports will be made public, and Campbell says he "would not rule out open meetings", although public access would not be relevant on every occasion.

The members of the commission include Martin Bobrow, professor of genetics at the University of Cambridge, the Reverend Dr John Polkinghorne, a former physicist who is also chairman of the Advisory Committee on Genetic Testing, and George Poste, chairman of research and development at SmithKline Beecham. Lay interests will be represented by Moira Stuart, a newsreader on BBC television. The secretariat will be based at the Office of Science and Technology, which will finance the commission jointly with the Department of Health.

Claire O'Brien 